\title{
FAKTOR-FAKTOR YANG MEMPENGARUHI AGRESIVITAS PAJAK PADA PERUSAHAAN MANUFAKTUR YANG TERDAFTAR DI BEI 2013-2015
}

\author{
Djeni Indrajati $\mathbf{W}^{\mathbf{1}}$, Sandy Djumena ${ }^{2}$, Yuniarwati ${ }^{3}$ \\ 1,2,3 Jurusan S1 Akuntansi, Universitas Tarumanagara \\ 1djenii@fe.untar.ac.id \\ ${ }^{2}$ sandydjumena94@gmail.com \\ 3yuniarwati@fe.untar.ac.id
}

\begin{abstract}
ABSTRAK
Beberapa penelitian tentang faktor yang mempengaruhi agresivitas pajak telah dilakukan dengan hasil yang belum konsisten. Tujuan penelitian ini adalah untuk menguji secara empiris faktor likuiditas, leverage, capital intensity, komisaris independen dengan agresivitas pajak perusahaan. Populasi dalam penelitian ini adalah perusahaan manufaktur yang terdaftar di Bursa Efek Indonesia dan 63 perusahaan terpilih sebagai sampel. Analisis data dilakukan dengan statistic deskriptif, uji asumsi klasik dan uji hipotesis (analisis regresi berganda, uji $F$ dan uji t). Hasil penelitian menunjukkan hanya likuiditas yang memiliki pengaruh signifikan terhadap agresivitas pajak perusahaan sedangkan pengujian secara simultan memiliki pengaruh. Didapati juga bahwa semua variabel independen mempunyai pengaruh positif terhadap agresivitas pajak, sehingga hipotesis H2 dan H4 ditolak. Likuiditas perusahaan agaknya lebih ditujukan untuk berekspansi jangka pendek, dan komisaris independen belum mampu meredam agresivitas pajak perusahaan.
\end{abstract}

Kata Kunci: Likuiditas, Leverage, Capital Intensity, Komisaris Independen, Agresivitas Pajak

\section{PENDAHULUAN}

Indonesia merupakan salah satu negara dengan jumlah penduduk terbesar di dunia serta memiliki sumber daya alam yang melimpah dengan lokasi yang strategis. Hal tersebut menjadikan adanya banyak perusahaan sehingga penerimaan negara dari sektor pajak dapat semakin meningkat. Sementara itu, perusahaan menganggap pajak sebagai beban yang akan mengurangi laba perusahaan, sehingga perusahaan cenderung berusaha mencari strategi dalam mengurangi beban pajaknya. Strategi tersebut dimaksudkan agar perusahaan tetap memperoleh laba yang optimal. Menurut Suyanto dan Supramono (2012:167) perusahaan dianggap semakin agresif terhadap pajak bila semakin banyak celah yang digunakan. Menurut Frank, Lynch dan Rego (2009:468), agresivitas pajak perusahaan merupakan tindakan manipulasi terhadap Penghasilan Kena Pajak melalui tindakan perencanaan pajak, baik dengan cara yang tergolong legal (tax avoidance) ataupun ilegal (tax evasion).

Beberapa peneliti sebelumnya berupaya untuk mengetahui faktor-faktor yang mempengaruhi agresivitas pajak perusahaan. Salah satu faktor yang diteliti adalah leverage perusahaan. Leverage dapat menunjukkan besarnya pinjaman yang dilakukan oleh perusahaan. Likuiditas merupakan kemampuan perusahaan dalam memenuhi kewajibannya atas utang jangka pendek dengan memanfaatkan aktiva lancarnya. Capital intensity menunjukkan besarnya investasi perusahaan terhadap aset tetapnya. Penelitian lain menggunakan komisaris independen sebagai varibel independen yang mempengaruhi agresivitas pajak.

Penelitian ini berupaya untuk mengintegrasikan penelitian-penelitian sebelumnya yang belum konsisten, dengan menganalisis kembali faktor-faktor yang mempengaruhi agresivitas pajak, yaitu leverage, likuiditas, capital intensity, dan komisaris independen. Penelitian ini menggunakan sampel perusahaan manufaktur yang terdaftar di Bursa Efek Indonesia dengan pembatasan periode pengamatan selama tahun 2013-2015, dengan Laporan keuangan yang bertahun buku 1 jan sd 31 Des, memiliki laba tahunan,, dengan mata uang rupiah dan telah diaudit. 


\section{TINJAUAN PUSTAKA}

\section{Definisi pajak}

Terdapat pada Pasal 1 angka 1 Undang-undang No. 16 Tahun 2009 tentang Ketentuan Umum dan Tata Cara Perpajakan, yang menyebutkan bahwa pajak adalah kontribusi wajib kepada negara yang terutang oleh orang pribadi atau badan yang bersifat memaksa berdasarkan undangundang, dengan tidak mendapatkan imbalan secara langsung dan digunakan untuk keperluan negara bagi sebesar-besarnya kemakmuran rakyat bidang sosial dan ekonomi. Sebagai contoh, tarif progresif pada Pajak Penghasilan dimaksudkan agar penerima penghasilan yang lebih tinggi akan memberikan kontribusi yang tinggi pula, hal tersebut bertujuan untuk pemerataan pendapatan.

\section{Agresivitas Pajak}

Menurut Frank, Lynch, dan Rego (2009:468), agresivitas pajak didefinisikan sebagai tindakan manipulasi terhadap Penghasilan Kena Pajak melalui tindakan perencanaan pajak, baik dengan cara yang tergolong legal (tax avoidance) ataupun ilegal (tax evasion). Dalam penelitian ini, agresivitas pajak diukur menggunakan rasio effective tax rate. Rasio ini banyak digunakan oleh berbagai penelitian terdahulu karena dianggap dapat memperlihatkan perbedaan antara laba menurut akuntansi dengan laba menurut fiskal. Perhitungan dari effective tax rate dapat dilakukan dengan menghitung total tax expense dibagi dengan pre-tax income (Suyanto dan Supramono, 2012:170).

\section{Leverage}

Leverage menggambarkan perbandingan antara total utang perusahaan dengan total aset yang dimilikinya. Perusahaan mengatur sedemikian rupa penggunaan utang dalam membiayai asetnya. Menurut Brooks (2013:459) leverage adalah "a company's ability to meet its long term debt obligation." dari pengertian tersebut, leverage menunjukkan kegiatan perusahaan dalam melakukan pendanaannya. Nilai rasio leverage yang semakin tinggi menunjukkan bahwa perusahaan semakin banyak melakukan pinjaman dan turut berdampak pada timbulnya beban bunga yang semakin besar. Oleh karena itu, perusahaan dengan nilai rasio leverage yang tinggi cenderung memiliki tingkat agresivitas pajak yang tinggi, yang diketahui dari rendahnya nilai effective tax rate, yang berarti memiliki hubungan positif.

\section{Likuiditas}

Menurut Weygandt, Kimmel, dan Kieso (2013:695) likuiditas adalah "a ratio to measure the short-term ability of the company to pay its maturing obligations and to meet unexpected needs for cash." Menurut Brooks (2013: 457) likuiditas adalah “a ratio to measure a company's ability to meet its short term debt obligations in a timely fashion." Dalam hubungannya dengan pajak, perusahaan yang memiliki likuiditas yang tinggi menunjukkan kemampuan perusahaan yang baik dalam memenuhi utang jangka pendeknya, yang berarti mempunyai hubungan negatif.

\section{Capital Intensity}

Penyusutan atas aset tetap merupakan biaya yang dapat dikurangkan sebelum perhitungan pajak menurut standar akuntansi dan tidak bertentangan dengan hukum pajak. Proporsi aset tetap yang lebih besar akan menyebabkan beban depresiasi yang semakin besar pula, sehingga penghasilan yang dikenakan pajak akan semakin kecil dan ETR pun semakin kecil. 
Terkait dengan pajak, Rodriguez dan Arias (2012:63) mengatakan bahwa keberadaan aset tetap memungkinkan perusahaan untuk mengurangi beban pajaknya atas penyusutan aset tetap perusahaan setiap tahunnya. Oleh karena itu, perusahaan yang memiliki nilai capital intensity yang tinggi cenderung memiliki nilai ETR rendah yang menggambarkan bahwa perusahaan agresif terhadap pajak, atau hubungannya positif.

\section{Komisaris Independen}

Berdasarkan Peraturan Nomor IX.I.5 Lampiran Keputusan Ketua BAPEPAM Kep-41/PM/2003, komisaris independen adalah anggota komisaris yang (1) berasal dari luar emiten atau perusahaan publik, (2) tidak mempunyai saham baik langsung maupun tidak langsung pada emiten atau perusahaan publik, (3) tidak mempunyai hubungan afiliasi dengan emiten atau perusahaan publik, komisaris, direksi, atau pemegang saham utama emiten atau perusahaan publik, dan (4) tidak memiliki hubungan usaha baik langsung maupun tidak langsung yang berkaitan dengan kegiatan usaha emiten atau perusahaan publik. Proporsi komisaris independen diatur dalam Keputusan Direksi PT Bursa Efek Jakarta Nomor Kep-305/BEJ/07-2004 bahwa salah satu syarat pencatatan saham bagi calon perusahaan tercatat adalah memiliki komisaris independen sekurang-kurangnya 30\% dari jajaran anggota Dewan Komisaris. Komisaris independen merupakan pihak yang netral, sehingga keberadaannya pada perusahaan diharapkan dapat meminimalisasi tindakan agresivitas pajak pada perusahaan, atau berarti hubungannya negatif.

\section{METODE PENELITIAN}

\section{Definisi Variabel}

Variabel dependen dalam penelitian ini adalah agresivitas pajak. Agresivitas pajak dalam penelitian ini diukur dengan effective tax rate (ETR), yaitu dengan perhitungan total tax expense dibagi dengan pre-tax income.

Variabel independennya ada 4, yaitu:

1. Leverage

Leverage menunjukkan kemampuan perusahaan dalam memenuhi kewajiban utang jangka panjangnya. Leverage dalam penelitian ini diukur dengan debt to asset ratio, yaitu dengan perhitungan total debt dibagi dengan total asset.

2. Likuiditas

Likuiditas menunjukkan kemampuan perusahaan dalam memenuhi kewajiban jangka pendeknya. Likuiditas dalam penelitian ini diukur dengan current ratio, yaitu dengan perhitungan current asset dibagi dengan current liability.

3. Capital Intensity

Capital Intensity menunjukkan seberapa besar perusahaan berinvestasi dalam bentuk fixed asset. Capital Intensity dalam penelitian ini diukur dengan capital intensity ratio, yaitu dengan perhitungan fixed asset dibagi dengan total asset.

4. Komisaris Independen Komisaris independen merupakan bagian dari dewan komisaris yang tidak terikat oleh salah satu pihak. Komisaris independen dalam penelitian ini diukur dengan perhitungan total komisaris independen dibagi dengan total dewan komisaris. 


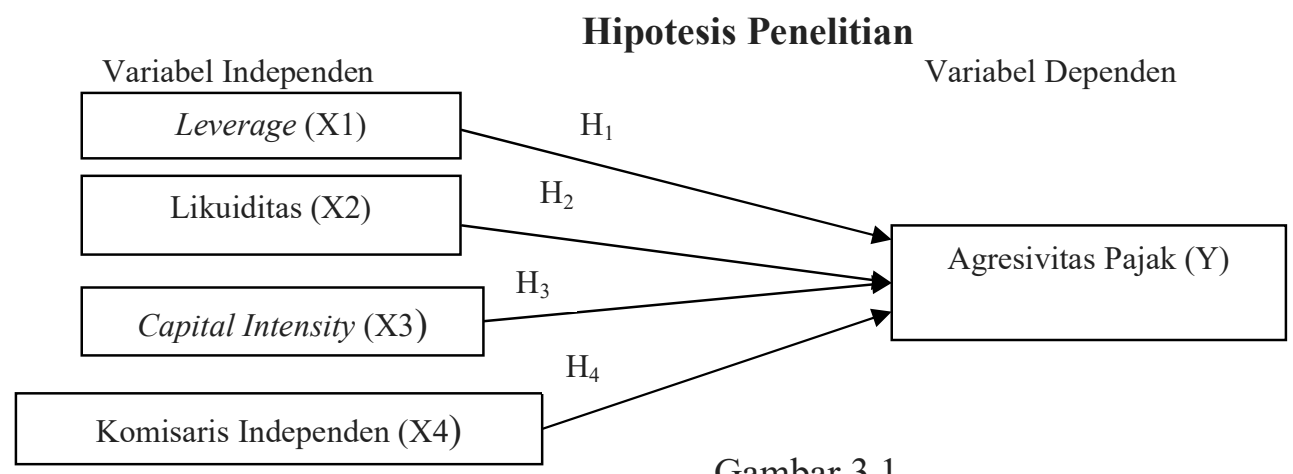

Gambar 3.1

Bagan Model Penelitian

Hipotesis merupakan jawaban sementara terhadap permasalahan dalam suatu penelitian. Hipotesis yang diuji dalam penelitian ini adalah:

$\mathrm{H}_{1}$ : Leverage memiliki Pengaruh dan hubungan positif terhadap agresivitas pajak perusahaan.

$\mathrm{H}_{2}$ : Likuiditas memiliki Pengaruh dan hubungan negatif terhadap agresivitas pajak perusahaan.

$\mathrm{H}_{3}$ : Capital Intensity memiliki Pengaruh dan hubungan positif terhadap agresivitas pajak

perusahaan.

$\mathrm{H}_{4}$ : Komisaris independen memiliki Pengaruh dan hubungan negatif terhadap agresivitas pajak perusahaan.

\section{Teknik Pengujian Hipotesis}

\section{Regresi Linear Berganda}

Untuk menganalisis penelitian yang memiliki lebih dari satu variabel independen dengan satu variabel dependen, maka penelitian ini menggunakan analisis regresi berganda (multiple regression). Persamaan regresi berganda untuk pengujian hipotesis dalam penelitian ini dirumuskan dengan:

$$
A P_{i t}=\alpha+\beta 1 \operatorname{Lev}_{i t}+\beta 2 \operatorname{Liq}_{i t}+\beta 3 C I_{i t}+\beta 4 \mathrm{KI}_{i t}+e_{i t}
$$

Keterangan:

Apit

: Agresivitas pajak perusahaan $i$ pada periode $t$ yang diukur dengan menggunakan model $E T R_{i t .}$

A : konstanta.

$\beta 1, \beta 2, \beta 3, \beta 4:$ koefisien regresi.

Lev $\quad:$ Leverage dari perusahaan $i$ pada periode ke $t$.

$\operatorname{Liq}_{i t} \quad$ : Likuiditas dari perusahaan $i$ pada periode ke $t$.

$C I_{i t} \quad:$ Capital Intensity dari perusahaan $i$ pada periode ke $t$.

$K I_{i t} \quad$ : Jumlah komisaris independen dibandingkan dengan jumlah anggota komisaris independen

$\mathrm{e}_{\text {it }}$ : error terms.

\section{ANALISIS DAN PEMBAHASAN}

Data penelitian ini adalah data sekunder berupa laporan keuangan dan laporan tahunan yang telah diaudit yang diperoleh dengan mengunjungi situs Bursa Efek Indonesia di internet, yaitu www.idx.co.id. Pemilihan sampel dengan metode purposive sampling, yaitu ditentukan jumlah perusahaan manufaktur yang terdaftar hingga akhir periode 2015 sebanyak 143, dikurangi yang 
mengalami kerugian 37 , yang mata uangnya bukan rupiah 25 , tidak terdaftar berturutan 18 , sehingga tertinggal 63 perusahaan saja. Dengan masa 3 tahun dan dikurangi outlier 42, maka N menjadi 147. Tujuan penggunaan metode ini agar sampel yang terpilih untuk penelitian adalah sampel yang relevan dengan penelitian ini sehingga hasil yang diperoleh dari penelitian ini lebih akurat dan tepat. Pengolahannya dengan SPSS versi 23.

Tabel 4.1 Hasil Analisis Statistik Deskriptif

Descriptive Statistics

\begin{tabular}{lcrrcr}
\hline & $\mathrm{N}$ & Minimum & Maximum & Mean & Std. Deviation \\
\hline ETR & 147 & .03358 & .36811 & .2468019 & .04392933 \\
\hline DAR & 147 & .07382 & .88090 & .4063472 & .17769266 \\
\hline CR & 147 & .51391 & 13.87127 & 2.7549586 & 2.39546415 \\
\hline CIR & 147 & .04490 & .84296 & .3315828 & .16697469 \\
\hline KI & 147 & .25000 & 1.00000 & .4057096 & .13000435 \\
\hline Valid N (listwise) & 147 & & & & \\
\hline \multicolumn{5}{c}{ Sumber: Hasil Pengolahan dengan SPSS 23 }
\end{tabular}

Sumber: Hasil Pengolahan dengan SPSS 23

Variabel dependen agresivitas pajak yang diproksikan dengan Effective Tax Rates (ETR) memiliki nilai rata-rata 0,2468019 . Angka tersebut menunjukkan rata-rata beban pajak yang ditanggung oleh perusahaan sebesar $24 \%$ dari laba sebelum Pajak Penghasilan yang dimiliki oleh perusahaan. Variabel independen leverage yang diproksikan dengan Debt to Asset Ratio (DAR) memiliki nilai rata-rata 0,4063472. Angka tersebut menunjukkan rata-rata total utang yang dimiliki oleh perusahaan sebesar $41 \%$ dari $100 \%$ atau keseluruhan aset yang dimiliki perusahaan. Variabel independen likuiditas yang diproksikan dengan Current Ratio $(C R)$ memiliki nilai ratarata 2,7549586. Angka tersebut menunjukkan rata-rata aset lancar yang dimiliki perusahaan 2,75 kali lebih banyak dari keseluruhan utang jangka pendeknya..

Variabel independen capital intensity yang diproksikan dengan Capital Intensity Ratio (CIR) memiliki nilai rata-rata 0,3315828 . Angka tersebut menunjukkan rata-rata nilai aset tetap yang dimiliki perusahaan sebesar 33\% dari keseluruhan aset yang dimilikinya. Variabel independen komisaris independen (KI) memiliki nilai rata-rata 0,4057096. Angka tersebut menunjukkan rata-rata proporsi dari komisaris independen yang dimiliki oleh perusahaan sebesar $40 \%$ dari total dewan komisaris.

Setelah mengetahui gambaran data dalam penelitian ini melalui analisis statistik deskriptif dan melakukan uji asumsi klasik terhadap data dalam penelitian ini telah lolos, maka tahap berikutnya yang dapat dilakukan adalah analisis regresi. Analisis regresi berganda dalam penelitian ini menggunakan tingkat keyakinan 95\%, maka tingkat signifikansinya adalah 5\%.

Hasil dari regresi dalam penelitian ini ditunjukkan dalam Tabel 4.2

Tabel 4.2 Hasil Regresi

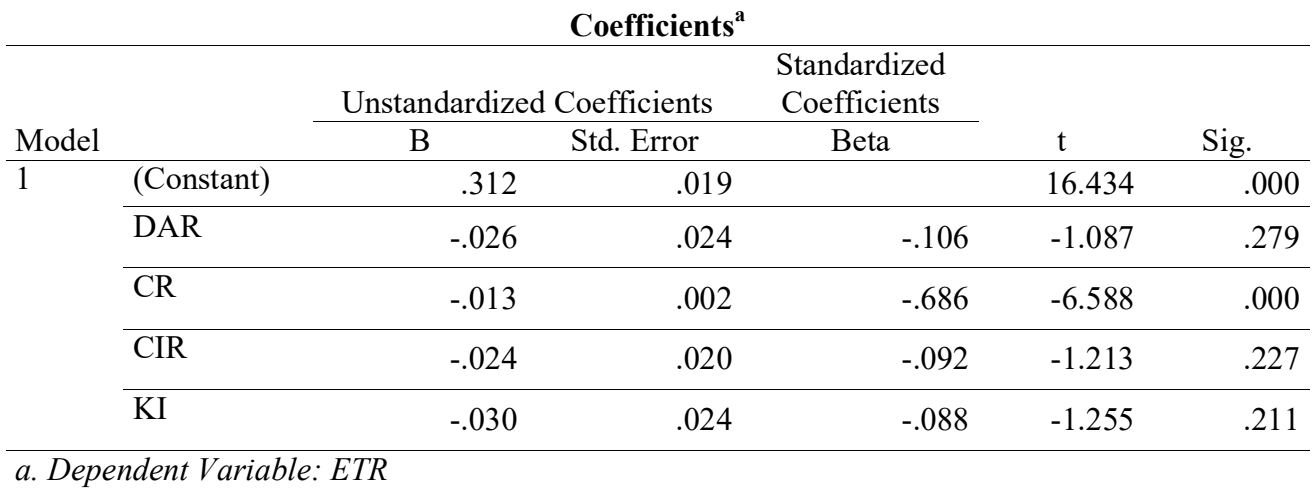


Sumber: Hasil Pengolahan dengan SPSS 23

Dari Tabel 4.2 dapat diketahui konstanta dan koefisien untuk masing-masing variabel independen dalam penelitian ini sehingga model regresi berganda yang digunakan dalam penelitian ini adalah:

$$
A P_{i t}=0,312-0,026 \mathrm{Lev}_{i t}-0,013 \mathrm{Liq}_{i t}-0,24 \mathrm{CI}_{i t}-0,3 \mathrm{KI}_{i t}
$$

Konstanta dalam model regresi di atas menunjukkan angka 0,312. Angka tersebut merupakan besarnya tingkat agresivitas pajak perusahaan pada saat leverage, likuiditas, capital intensity, dan komisaris independen memiliki nilai 0 . Nilai koefisien dari variabel leverage adalah $-0,026$. Nilai koefisien tersebut memiliki tanda negatif yang menunjukkan hubungan yang berlawanan antara leverage yang diproksikan dengan debt to asset ratio $(D A R)$ terhadap effective tax rate $(E T R)$. Dari angka tersebut dapat dijelaskan bahwa setiap kenaikan $1 \%$ leverage akan mengakibatkan penurunan pada nilai effective tax rate sebesar $0,026 \%$.

Nilai koefisien dari variabel likuiditas adalah -0,013. Nilai koefisien tersebut memiliki tanda negatif yang menunjukkan hubungan yang berlawanan antara likuiditas yang diproksikan dengan current ratio $(C R)$ terhadap effective tax rate $(E T R)$. Dari angka tersebut dapat dijelaskan bahwa setiap kenaikan 1\% likuiditas akan mengakibatkan penurunan pada nilai effective tax rate sebesar 0,013\%.

Nilai koefisien dari variabel capital intensity adalah -0,24. Nilai koefisien tersebut memiliki tanda negatif yang menunjukkan hubungan yang berlawanan antara capital intensity yang diproksikan dengan capital intensity ratio (CIR) terhadap effective tax rate (ETR). Dari angka tersebut dapat dijelaskan bahwa setiap kenaikan 1\% capital intensity akan mengakibatkan penurunan pada nilai effective tax rate sebesar $0,24 \%$.

Nilai koefisien dari variabel komisaris independen adalah -0,3. Nilai koefisien tersebut memiliki tanda negatif yang menunjukkan hubungan yang berlawanan antara komisaris independen yang diproksikan dengan capital intensity ratio $(C I R)$ terhadap effective tax rate $(E T R)$. Dari angka tersebut dapat dijelaskan bahwa setiap kenaikan $1 \%$ komisaris independen akan mengakibatkan penurunan pada nilai effective tax rate sebesar $0,3 \%$.

\section{Uji F}

Uji F digunakan untuk menguji signifikansi pengaruh semua variabel independen terhadap variabel dependen secara bersama-sama atau simultan (Ghozali, 2016:96). Hasil uji F yang telah dilakukan dapat dilihat pada Tabel 4.3 berikut ini:

\begin{tabular}{|c|c|c|c|c|c|c|}
\hline \multicolumn{7}{|c|}{$\begin{array}{c}\text { Tabel } 4.3 \text { Hasil Uji F } \\
\text { ANOVA }^{\mathbf{a}}\end{array}$} \\
\hline Model & & Sum of Squares & $\mathrm{df}$ & Mean Square & $\mathrm{F}$ & Sig. \\
\hline \multirow[t]{3}{*}{1} & Regression & .094 & 4 & .023 & 17.702 & $.000^{\mathrm{b}}$ \\
\hline & Residual & .188 & 142 & .001 & & \\
\hline & Total & .282 & 146 & & & \\
\hline
\end{tabular}

b. Predictors: (Constant), KI, DAR, CIR, CR

Sumber: Hasil pengolahan dengan SPSS 23

Pada Tabel 4.3, dapat diketahui besarnya nilai signifikansi adalah 0,000. Angka tersebut lebih kecil dari 0,05 sehingga dapat dikatakan bahwa variabel independen dalam penelitian ini, yaitu leverage, likuiditas, capital intensity, dan komisaris independen secara simultan memiliki pengaruh terhadap variabel dependen agresivitas pajak. 


\section{Uji t}

Uji statistik t merupakan uji yang menunjukkan seberapa jauh pengaruh satu variabel independen secara individual dalam menerangkan variasi variabel dependen Ghozali (2016:97). Berikut ini adalah Tabel 4.4 yang menunjukkan hasil uji t:

Tabel 4.4 Hasil Uji t

\begin{tabular}{|c|c|c|c|c|c|c|}
\hline \multicolumn{7}{|c|}{ Coefficients $^{a}$} \\
\hline \multirow{2}{*}{\multicolumn{2}{|c|}{ Model }} & \multicolumn{2}{|c|}{ Unstandardized Coefficients } & \multirow{2}{*}{$\begin{array}{c}\begin{array}{c}\text { Standardized } \\
\text { Coefficients }\end{array} \\
\text { Beta } \\
\end{array}$} & \multirow[b]{2}{*}{$\mathrm{t}$} & \multirow[b]{2}{*}{ Sig. } \\
\hline & & $\mathrm{B}$ & Std. Error & & & \\
\hline \multirow[t]{5}{*}{1} & (Constant) & .312 & .019 & & 16.434 & .000 \\
\hline & DAR & -.026 & .024 & -.106 & -1.087 & .279 \\
\hline & $\mathrm{CR}$ & -.013 & .002 & -.686 & -6.588 & .000 \\
\hline & CIR & -.024 & .020 & -.092 & -1.213 & .227 \\
\hline & KI & -.030 & .024 & -.088 & -1.255 & .211 \\
\hline
\end{tabular}

Sumber: Hasil pengolahan dengan SPSS 23

Berikut ini adalah penjelasan mengenai pengaruh dan hubungan antara variabel leverage, likuiditas, capital intensity, dan komisaris independen terhadap agresivitas pajak:

Dari Tabel di atas, diketahui bahwa variabel leverage memiliki nilai signifikansi 0,279. Nilai tersebut lebih besar dari nilai signifikansi 0,05 , maka dapat disimpulkan bahwa variabel leverage tidak memiliki pengaruh yang signifikan terhadap agresivitas pajak. Ada faktor tertentu yang membuat perusahaan tidak memanfaatkan beban bunga yang timbul dari utang untuk mengurangi beban pajak. Perusahaan memiliki pertimbangan apabila utang yang dimiliki perusahaan terlalu besar, maka resiko yang dihadapi perusahaan juga semakin besar. Selain itu, besarnya jumlah utang yang dimiliki perusahaan dapat menurunkan kepercayaan investor karena investor menggangap perusahaan tersebut memiliki resiko yang besar.

Hasil penelitian ini sesuai dengan hasil penelitian Hsieh (2012), Kurniasih dan Sari (2013), Kraft (2014), Ardyansah dan Zulaikha (2014), Tiaras dan Wijaya (2015) yang menyatakan bahwa leverage perusahaan tidak berpengaruh signifikan terhadap effective tax rate (ETR). Sebaliknya, hasil penelitian ini tidak sesuai dengan hasil penelitian Suyanto dan Supramono (2012), Rodriguez dan Arias (2012), Nugraha dan Meiranto (2015) yang menyatakan bahwa leverage perusahaan memiliki pengaruh signifikan terhadap effective tax rate. Sementara, hubungan negatif leverage terhadap effective tax rate dalam penelitian ini sesuai dengan hasil penelitian Nugraha dan Meiranto (2015). Hal berbeda diungkapkan oleh penelitian yang dilakukan oleh Suyanto dan Supramono (2012) serta Ardyansah dan Zulaikha (2014) yang menyatakan adanya hubungan positif leverage terhadap effective tax rate.

Variabel likuiditas memiliki nilai signifikansi 0,000. Nilai tersebut kurang dari nilai signifikansi 0,05, maka dapat disimpulkan bahwa variabel likuiditas memiliki pengaruh yang signifikan terhadap agresivitas pajak.. Namun dalam penelitian ini menunjukkan bahwa semakin tinggi nilai likuiditas perusahaan semakin rendah nilai effective tax rate, yang berarti tingkat agresivitas pajak perusahaan semakin meningkat. Hal tersebut dapat terjadi karena adanya kemungkinan perusahaan menggunakan aset lancarnya untuk meningkatkan kegiatan operasional perusahaan dalam menghasilkan laba. Hasil penelitian ini tidak sesuai dengan hasil penelitian yang dilakukan Suyanto dan Supramono (2012) serta Tiaras dan Wijaya (2015) yang menyatakan 
bahwa likuiditas tidak memiliki pengaruh yang signifikan terhadap agresivitas pajak. Sementara, hubungan negatif likuiditas terhadap effective tax rate dalam penelitian ini sesuai dengan hasil penelitian yang dilakukan oleh Suyanto dan Supramono (2012).

Variabel capital intensity memiliki nilai signifikansi 0,227. Nilai tersebut lebih besar dari nilai signifikansi 0,05, maka dapat disimpulkan bahwa variabel capital intensity tidak memiliki pengaruh yang signifikan terhadap agresivitas pajak. Capital intensity menunjukkan besarnya aset tetap yang dimiliki perusahaan dari keseluruhan aset yang dimilikinya. Aset tetap memiliki beban penyusutan setiap tahunnya yang dapat digunakan untuk mengurangi laba perusahaan sebelum perhitungan Pajak Penghasilan. Namun, dalam penelitian ini variabel capital intensity tidak memiliki pengaruh yang signifikan. Hasil penelitian ini sesuai dengan hasil penelitian Ardyansah dan Zulaikha (2014), Nugraha dan Meiranto (2015) yang menyatakan bahwa capital intensity tidak memiliki pengaruh signifikan terhadap agresivitas pajak. Sebaliknya, hasil penelitian ini tidak sesuai dengan hasil penelitian Hsieh (2012) serta Rodriguez dan Arias (2012) yang menyatakan bahwa capital intensity memiliki pengaruh signifikan terhadap agresivitas pajak. Hubungan negatif capital intensity terhadap effective tax rate dalam penelitian ini sesuai dengan hasil penelitian Nugraha dan Meiranto (2015), namun berlainan dengan hasil penelitian Ardyansah dan Zulaikha (2014) yang menyatakan arah/hubungan yang positif capital intensity terhadap effective tax rate.

Variabel komisaris independen memiliki nilai signifikansi 0,211. Nilai tersebut lebih besar dari nilai signifikansi 0,05 , maka dapat disimpulkan bahwa variabel komisaris independen tidak memiliki pengaruh yang signifikan terhadap agresivitas pajak. Komisaris independen adalah pihak yang tidak terafiliasi dengan perusahaan. Hasil penelitian ini sesuai dengan hasil penelitian Kurniasih dan Sari (2013), Tiaras dan Wijaya (2015) yang menunjukkan bahwa komisaris independen tidak memiliki pengaruh signifikan terhadap agresivitas pajak. Sebaliknya, hasil penelitian ini tidak sesuai dengan hasil penelitian Suyanto dan Supramono (2012) serta Ardyansah dan Zulaikha (2014) yang menunjukkan bahwa komisaris independen memiliki pengaruh yang signifikan terhadap agresivitas pajak. Hubungan negatif komisaris independen terhadap effective tax rate dalam penelitian ini sesuai dengan hasil penelitian Suyanto dan Supramono (2012), namun berlainan dengan hasil penelitian Ardyansah dan Zulaikha (2014) yang menyatakan hubungan positif komisaris independen terhadap effective tax rate.

\section{Uji $\mathbf{R}^{2}$}

Menurut Ghozali (2016:95), koefisien determinasi (R2) mengukur seberapa jauh kemampuan model dalam menerangkan variasi variabel dependen. Nilai dari koefisien determinasi berada diantara 0 sampai dengan 1 .. Berikut ini disajikan Tabel 4.5 mengenai hasil uji $\mathrm{R}^{2}$.

\begin{tabular}{|c|c|c|c|c|}
\hline \multicolumn{5}{|c|}{$\begin{array}{c}\text { Tabel 4.5 Hasil Uji R } 2 \\
\text { Model Summary }\end{array}$} \\
\hline Model & $\mathrm{R}$ & R Square & Adjusted R Square & $\begin{array}{l}\text { Std. Error of the } \\
\text { Estimate }\end{array}$ \\
\hline 1 & $.577^{\mathrm{a}}$ & .333 & .314 & .03638611 \\
\hline
\end{tabular}

Dari tabel di atas, dapat dilihat bahwa nilai koefisien determinasi adalah 0,314. Angka tersebut menunjukkan bahwa 31,4\% variabel dependen agresivitas pajak dapat dijelaskan oleh varibelvariabel independen dalam penelitian ini, yaitu leverage, likuiditas, capital intensity, dan komisaris independen. Sementara sisanya sebesar $68,6 \%$ dijelaskan oleh variabel lainnya, seperti profitabilitas, ukuran perusahaan, kepemilikan manajerial, dan lain-lain. 


\section{KESIMPULAN DAN SARAN}

Berdasarkan hasil pengujian dan analisis yang telah dilakukan, serta pembahasan yang dilakukan, maka dapat ditarik beberapa kesimpulan sebagai berikut:

1. Leverage tidak signifikan positif mempengaruhi agresivitas pajak. Koefisien regresi dari leverage memiliki tanda negatif yang menunjukkan hubungan negatif antara leverage terhadap effective tax rate, yaitu meningkatnya nilai leverage perusahaan akan menurunkan nilai effective tax rate sehingga agresivitas pajak perusahaan meningkat dan demikian sebaliknya.

2. Likuiditas signifikan negatif mempengaruhi agresivitas pajak. Koefisien regresi dari likuiditas memiliki tanda negatif yang menunjukkan hubungan negatif antara likuiditas terhadap effective tax rate, yaitu meningkatnya nilai likuiditas perusahaan akan menurunkan nilai effective tax rate sehingga agresivitas pajak perusahaan meningkat dan demikian sebaliknya.

3. Capital intensity tidak signifikan positif mempengaruhi agresivitas pajak. Koefisien regresi dari capital intensity memiliki tanda negatif yang menunjukkan hubungan negatif antara capital intensity terhadap effective tax rate, yaitu meningkatnya nilai capital intensity perusahaan akan menurunkan nilai effective tax rate sehingga agresivitas pajak perusahaan meningkat dan demikian sebaliknya.

4. Komisaris independen tidak signifikan negatif mempengaruhi agresivitas pajak. Koefisien regresi dari komisaris independen memiliki tanda negatif yang menunjukkan hubungan negatif antara komisaris independen terhadap effective tax rate, yaitu meningkatnya nilai komisaris independen perusahaan akan menurunkan nilai effective tax rate sehingga agresivitas pajak perusahaan meningkat dan demikian sebaliknya.

Saran yang diberikan bagi penelitian selanjutnya, yaitu:

1. Penelitian selanjutnya dapat dilakukan terhadap perusahaan pada bidang lainnya selain manufaktur agar ilmu dan pemahaman mengenai agresivitas pajak semakin berkembang dan komprehensif dengan menggunakan faktor yang berbeda dan menambah tahun pengamatan.

2. Penelitian ini dapat menjadi masukan bagi pemerintah dalam memahami tingkat agresivitas pajak pada perusahaan manufaktur di BEI sehingga dapat menentukan peraturan perpajakan yang tepat terhadap perusahaan-perusahaan tersebut.

\section{ACKNOWLEDGEMENT}

Terima Kasih kepada Bapak Rektor UNTAR, Bapak Dekan FE UNTAR, Bapak Direktur DPPM UNTAR, rekan peneliti dan pengolah data serta berbagai pihak yang telah membantu dan meberi semangat.

\section{REFERENSI}

Ardyansah, Danis dan Zulaikha. 2014. Pengaruh Size, Leverage, Profitability, Capital Intensity Ratio dan Komisaris Independen Terhadap Effective Tax Rate (ETR). Diponegoro Journal of Accounting, 3. (2). Hal 1-9

Brooks, Raymond M. 2013. Financial Management. Core Concepts. Second Edition. England: Pearson Education Limited

Frank, M.M., Lynch, L.J., \& Rego, S.O. 2009. Tax Reporting Aggressiveness and Its Relation to Aggressive Financial Reporting. The Accounting Review, 84. (2). Hal 467-496 
Ghozali, Imam. 2016. Aplikasi analisis multivariate dengan program SPSS. Edisi Delapan. Semarang: Badan Penerbit Universitas Diponegoro

Hsieh. 2012. New Evidence on Determinant of Corporate Effective Tax Rate. African Journal of Business Management, 6. (3). Hal 1177-1180

Keputusan Direksi PT Bursa Efek Jakarta Nomor Kep-305/BEJ/07-2004 tentang Peraturan Nomor I-A Tentang Pencatatan Saham dan Efek Bersifat Ekuitas Selain Saham yang Diterbitkan Oleh Perusahaan Tercatat

Kraft, Anastasia. 2014. What Really Affect German Firm's Effective Tax Rate?. International Journal of Financial Research, 5. (3). Hal 1-19

Kurniasih, Tommy dan Maria M Ratna Sari. 2013. Pengaruh Return on Assets, Leverage, Corporate Governance, Ukuran Perusahaan dan Kompensasi Rugi Fiskal pada Tax Avoidance. Buletin Studi Ekonomi. 18. (1). Hal 58-66

Nugraha, N.B. dan Meiranti, Wahyu. 2015. Pengaruh Corporate Social Responsibility, Ukuran Perusahaan, Profitabilitas, Leverage, dan Capital Intensity Terhadap Agresivitas Pajak. Diponegoro Journal of Accounting, 4. (4). Hal 1-14

Peraturan Nomor IX.I.5 Lampiran Keputusan Ketua BAPEPAM Kep-41/PM/2003 tentang Pembentukan dan Pedoman Pelaksanaan Kerja Komite Audit

Rodriguez, E.F. dan Arias, A.M. 2012. Do Business Characteristics Determine an Effective Tax Rate?. The Chinese Economy, 45. (6). Hal 60-83

Suyanto, Krisnata Dwi dan Supramono. 2012. Likuiditas, Leverage, Komisaris Independen, dan Manajemen Laba Terhadap Agresivitas Pajak Perusahaan. Jurnal Keuangan dan Perbankan. 16. (2). Hal 167-177

Tiaras, Irvan dan Wijaya, Henryanto. 2015. Pengaruh Likuiditas, Leverage, Manajemen Laba, Komisaris Independen, dan Ukuran Perusahaan Terhadap Agresivitas Pajak. Jurnal Akuntansi, 19. (3). Hal 380-397

Undang-Undang No. 16 Tahun 2009 tentang Perubahan Keempat Atas Undang-Undang Nomor 6 Tahun 1983 Tentang Ketentuan Umum dan Tata Cara Perpajakan

Undang-Undang No. 36 Tahun 2008 tentang Perubahan Keempat atas Undang- Undang Nomor 7 Tahun 1983 Tentang Pajak Penghasilan

Weygandt, Jerry J., Kimmel, Paul D., dan Kieso, Donald E. 2013. Financial Accounting First Edition. China: John Willey \& Sons. 